\title{
トンネル二次覆工
}

末永充弘 ${ }^{* 1} \cdot$ 北川修三 $* 2 \cdot$ 河合 尚 ${ }^{* 3}$ ・斉藤雅春 ${ }^{* 4}$

1.はじめに

最近のトンネル掘削技術の動向は, 山岳トンネル工法 では大型機械の導入, 省力化を追求した全断面掘削によ る急速施工の方向にあり, 多少地質が悪くても補助工法 を併用して安全性の確保が可能であればこの方が有効で あるとされている。また，地質等の地山条件が計せば長 孔発破や TBM の採用が検討されている。一方，シール ド工法においてもセグメントの構造解析技術の進歩のほ か, 施工面において送排泥管の自動接続, セグメントの 自動搬送・組立て, ビットライフの向上，日常掘削管理 の電算化等による省力化，工区の長大化，連続作業時間 の確保が可能となり合理化, 経済化が図られている。

掘削のほか，二次覆工の施工においても新しい考え方 や技術が導人されている。

シールド工法の場合は，セグメント止水シールにおい て水膨張タイプの研究成果による設計法の確立, 品質の 向上等により，内水压等の比較的大きな将来荷重を受け るトンネルを除いて通常，止水を目的とした二次覆工 は，巻厚分の内空余裕を考慮はするが，建設時施工しな い場合が多い。

一方，山岳工法では二次覆工を施工するのが通例であ る。覆工作業は, 狭险な坑内での競合作業となり, 技術 上も型枠の繰返し使用，重量物の移動，現地合わせの型 枠のセット等に対する合理的な対応策，坑内での出来 形，品質の確保等において課題が山積している。

ここでは二次覆工の型枠に関する新技術について，北 陸新幹線五里ケ峯トンネルでNATAによる我が国初の 1 打設長 $18 \mathrm{~m}$ のスチールフォームでの施工と, 秋間卜 ンネルでの鉄道初の掘削・覆工併進工法 (山岳 ECL) における型枠の設計を主体に述べる。なお，ECLにつ いては，一次覆工と二次覆工とを同時に施工する方式と なっている。

\footnotetext{
* 1 すえなが・みつひろ/日本鉄道建設公时 設計技術室 主任技師 (正会員)

＊2 きたがわ・しゅうぞう／同上＼cjkstart調査役

*3 かわい・ただし (株能谷組北関東支店 土木部長

* 4 さいとう・まさはる/鉄建建設(制)エンジニアリング本部 上木技 術部 機電技術課長
}

\section{NATM における二次覆工の型枠}

通常, NATM における二次覆工は，掘削後変位が収 束してトンネルを含む周辺地山の安定が確認された後に 施工される設計基準強度 $180 \mathrm{kgf} / \mathrm{cm}^{2}$, 巻厚 $30 \mathrm{~cm}$ 程度 の無筋コンクリートによっている。施工は, 掘削完了後 に一括して行う方法と, 掘削切羽から数百 $\mathrm{m}$ 後方で掘 削作業と併行して行う方法とがあり，前者を分離方式， 後者を併進方式と称している。二次覆工の型枠には, 移 動を可能にして多転用を目指したスチールフォームとバ ラセントルとがあるが，坑口や拡幅部等特殊な区間での 打込みを除いて 1 打設長 10.5 12 $\mathrm{m}$ 程度のスチール フォームを使用して連続的に施工しているケースが多 い。

線状構造物であるトンネル内での連続作業の効率化を 目途にスチールフォームにはさまざまな工夫がなされて いる。小断面での急速施工を図るため，スチールフォー

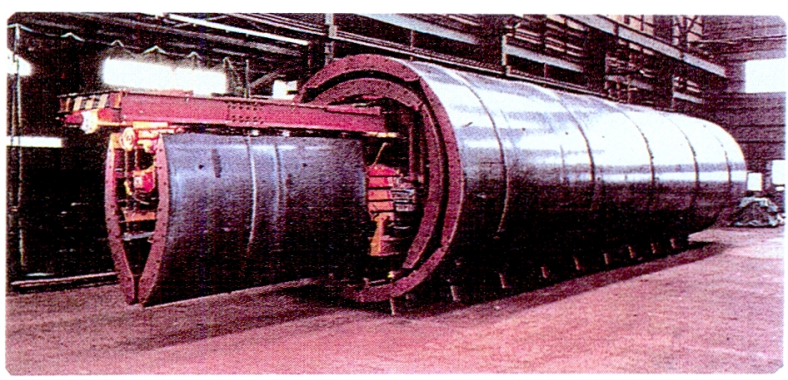

写真-1 テレスコピックスチールフォーム

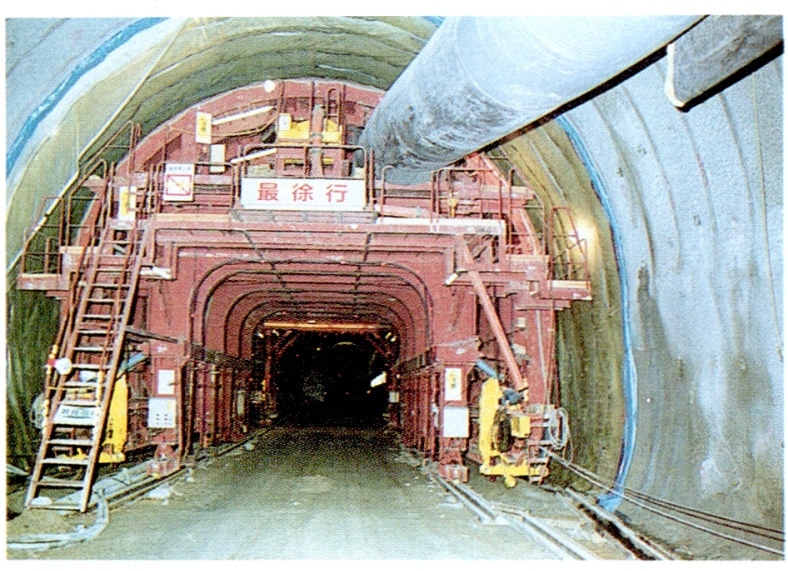

写真-2 ノンテレスコピックスチールフォーム 
ム内を既使用型枠を未施工箇所まで移動可能な構造とし た写真-1 に示すテレスコピックタイプと, 既打込み区 間を移動可能な写真一2 のノンテレスコピックタイプと があり, 通常, 後者が採用されている。

\section{1 スチールフォームの設計}

通常, スチールフォームの設計は, トンネル工区ごと に行っており, その設計荷重は, 実績や経験にてらし て, (1)鉛直荷重として二次覆工コンクリートの重量, (2) 吹上げ方式による上ぜめ圧力, (3)打上がり速度に対応す る側压, (4)フレーム等の所要鋼材自重等を考慮してお り, それぞれ関連する法規, 土木学会「コンクリート標 準示方書」,「トンネル標準示方書・同解説」等に則って 算定している。次に部材の設計は, 鋼材規格 SS400を 使用して許容応力度法により行っている。製作は, 通 常, メーカー側の工場で行い, 仮組立て検査を行って設 計図との照合の後, 現地に持込んでいる。

\section{2 二次覆工施工に関する最新技術}

機械化, システム化による作業の省力化, 二次覆工の 高品質化を目的として, 日々改善が図られているが, 二 次覆工型枠について最近の主要な技術をあげると次の之 おりである。
（1）型枠セット関係
1) スチールフォームの自動位置決めシステム
2) ジャッキの電動化, システム化
3）サイドフォームの油压ジャッキによる自動セッ トシステム
4) 自動妻枠セットシステム
5）目違い防止装置
(2) 打込み関係

1）打込み位置移動システム

2）分配弁を使用したコンクリート打込み配管切替 え装置

3）昇降, 旋回, 開閉可能な打込み注入口装置

4) 自動内部振動機作用システム

(3) 脱型関係

1) 洗浄システム

2) 自動ケレン装置（ベルトまたはロープ式, 㓥離 鼡塗布装置付き)

これらは現在, 必要により装備され活用されている。 特に, 防水シート破損防止を考慮した自動妻枠セット, 自動ケレン装置は, 省力化だけでなく作業の安全面にお いても開発の意義は大きいものと考えている。

\section{3 北陸新幹線五里ケ峯トンネルでの施工例}

五里ケ峯トンネルは, 軽井沢・長野間に位置する延長 $15.2 \mathrm{~km}$ の当区間の最長トンネルであり, 完成時期が 線区全体工期に重大な影響を与えるものと考えられ，急 速施工が最大の課題とされた。延長 $5 \mathrm{~km}$ 亡工区長が最 大の戸倉工区でも同様の主旨から, 掘削での 6 ブームガ ントリジャンボによる長孔発破工法採用のほか, 二次覆 工においても我が国で初めて延長 $18 \mathrm{~m}$ のスチール フォームを採用して施工の高速化を目指した。図一1に このスチールフォームの断面図を, 写真-3に全景を示 す。スチールフォームの長大化に伴う課題は収縮クラッ クの制御にあり, 通常, スチールフォーム長が 10.5 12 $\mathrm{m}$ の範囲にあるのも経験的にクラックの発生防止を考 慮した結果と考えられる。今回, 対応策として, 中間 9 $\mathrm{m}$ 位置に写真 -4 に示す目地設置型枠を設けて, これに 収縮クラックを誘発させて品質の確保を図ることとし

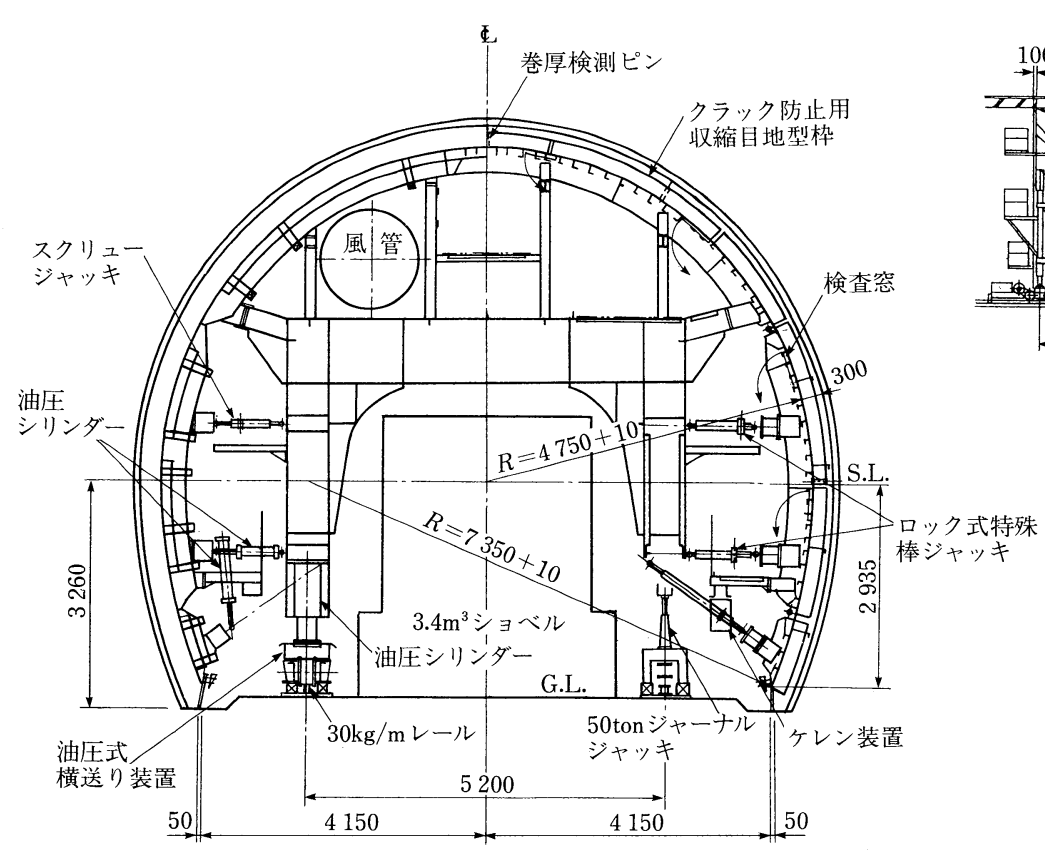

図-1＼cjkstart長スパン施エ用スチールフォーム断面図
側 面 図
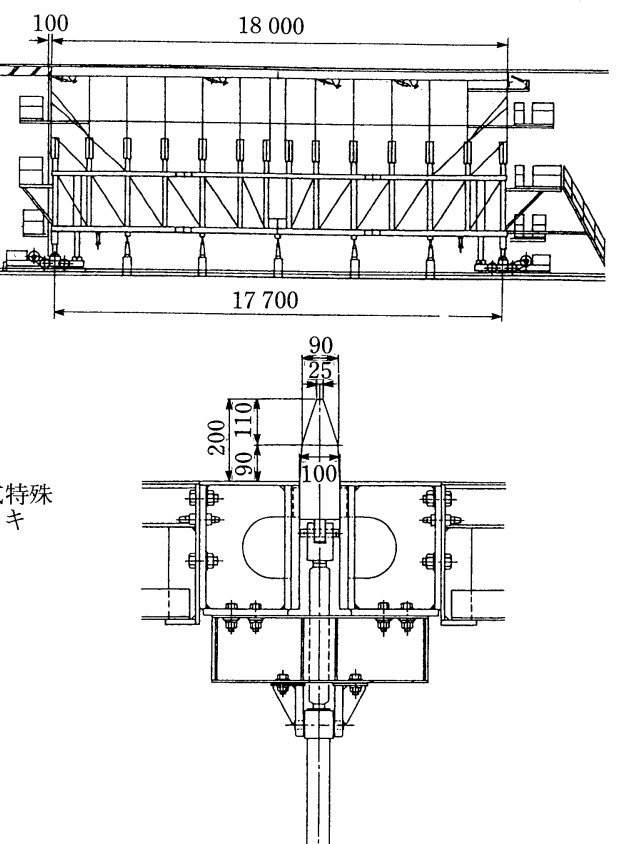

収縮目地型枠図 


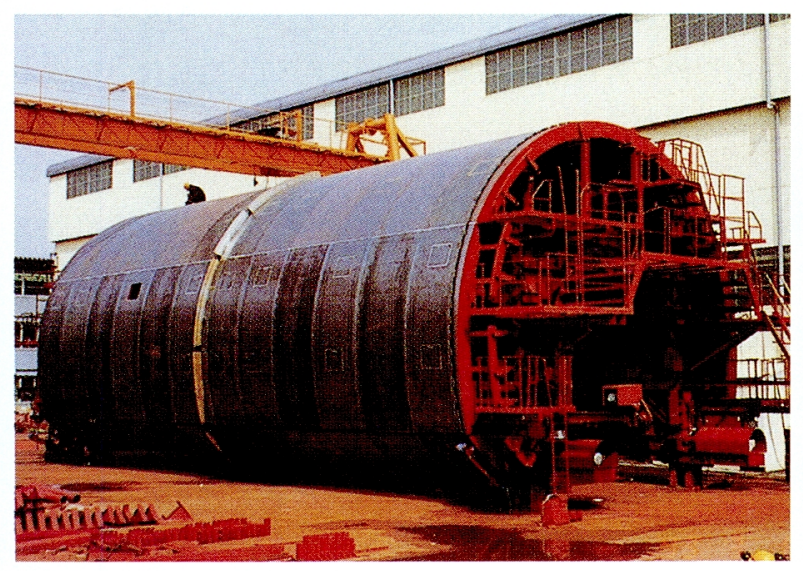

写真 -3 急速施工型長スパン全断面スチールフォーム $(L=18.0 \mathrm{M})$

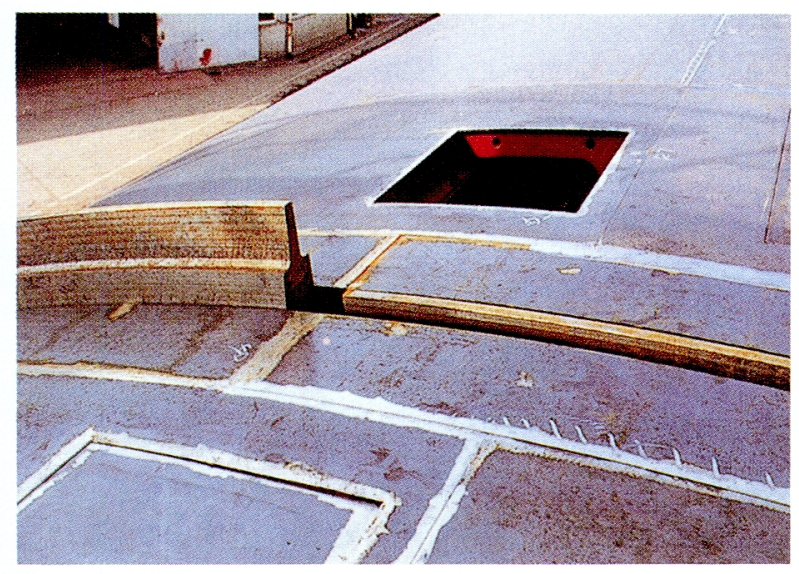

写真 -4 目地設置用型枠

た。目地深さは, 卷厚 $30 \mathrm{~cm}$ に対して $20 \mathrm{~cm}$ とした。 目地作成は，打込み時に全周を 11 ブロックに分割した 油圧式脱着型枠をセットし，コンクリートの硬化状況を 見てこれを引抜き，盲目地とした。これらの設備を使用 して掘削との併進で, 3 回/週（最大 4 回/週）之所期の 進行を確保するとともに収縮クラックの誘発効果が十分 発揮されたと考えている。

\section{ECL の型枠}

平成 4 年 3 月社団法人日本トンネル技術協会「ECL 工法指針（案)」によると, ECL 工法とは，(1)シルド の推進と同時にフレッシュコンクリートを加生して空隙 を充㙗し, 地山に密着させる工法, (2)加压によってフ レッシュコンクリートを密実化させる工法, のいずれか を満足する工法と定義されている。このため, 型枠は推 力の反力, プレス压等を受け, 前述の二次覆工の場合之 は異なる機能が要求され，これらを考慮して設計する必 要がある。ここでは，(1)の工法に相当する秋間トンネル における掘削覆工併進工法の例について述べる。

掘削覆工併推工法（以下 ECL 工法）は, シールドの テール部で内型枠, 妻枠と地山に囲まれた部位にコンク リートを直接打設し，プレスすることによって地山に密 着した密実な覆工コンクリートを形成する工法である。

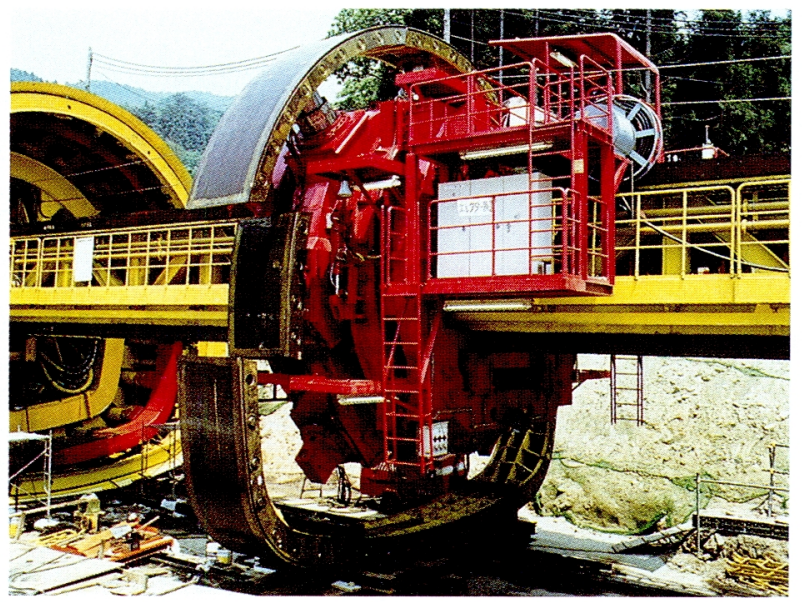

写真 -5 秋間トンネルの内型枠

このような工法の特徵から, 内型枠, 妻型枠には, コン クリートの自重, 側厈, 土压や水厈の外力のほか, シー ルド推力の反力が作用するため, これに耐える構造とす る必要がある。

\section{1 内型枠の機能}

ECL 工法で使用する内型染には，通常の二次覆工に 使用する型枠の機能以外に，次の機能を保持させる必要 がある。

（1）フレッシュコンクリートのプレス压を支持する 機能

シールドの推進に伴って, 加压状態を保持しながらフ レッシュコンクリートをテール部内に打込まなければな らない。このために, 内型枠はコンクリートを介して伝 達されるプレス压を支持する必要がある。

（2）コンクリートの養生期間中に，地山荷重支持 する機能

打込み後の若材齢コンクリートにも直ちに，直接土水 压などの外力が作用するために，所要の強度が発現する までの間は，内型枠がこれを支持する必要がある。

（3）シールドの推力を伝達する機能

掘削時のシールドの推力を内型枠で受け，付着力ある いは摩擦力などによってコンクリートへ伝達する方式を とっている。このために, 内型枠はシールドジャッキに よって発生する軸方向力に耐え得る強度と, 反力を得る ためのコンクリートとの付着力あるいは摩擦力が確保で きる構造とする必要がある。

（4）一定の装備数で繰り返し使用可能な機能

コンクリート硬化後, 順次再使用可能なものとし, 容 易に脱型, 移動, 組立ができる構造および機構とする必 要がある。

ECL 工法に用いる型枠は，上記に示した機能を有 し，かつ十分な剛性が必要である。

\section{2 内型枠の構造設計}

秋間トンネルで使用した内型枠は, 断面形状が馬蹄形 であること，また荷重が複雑なことを考慮して 2 次元構 造物として取り扱うのではなく，一端固定，他端自由な 


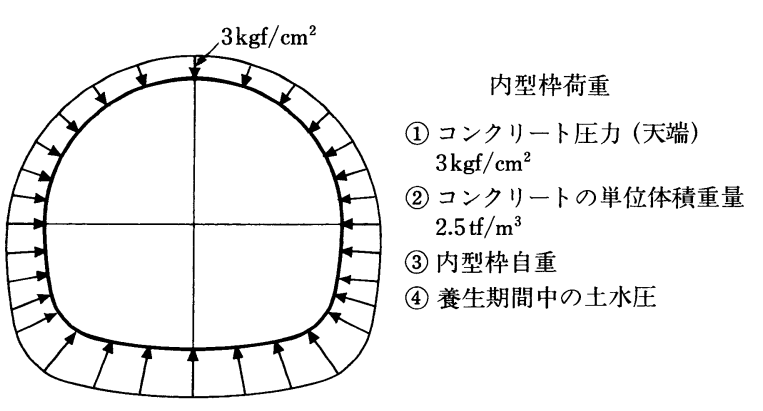

図-2 秋間トンネルの内型枠荷重条件

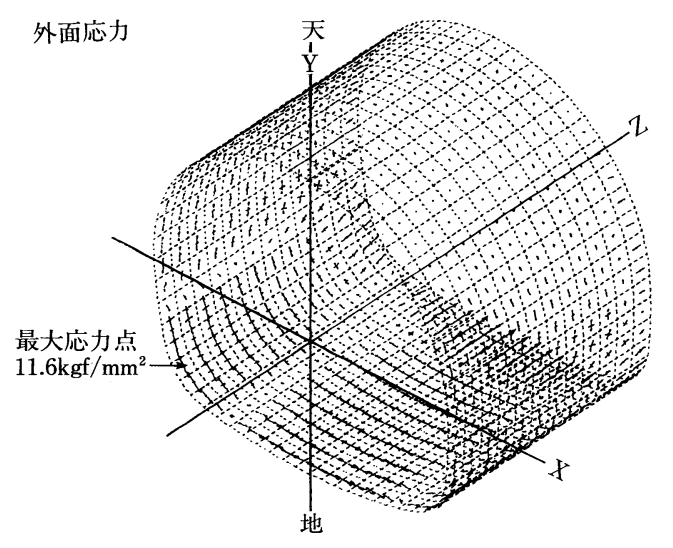

図-3＼cjkstart秋間トンネルの内型枠計算モデル

有限長さを持つ 3 次元円筒殼として, 有限要素法により 解析を行い, その結果発生する曲げモーメント, 軸力お よびそれらの発生位置より, 有効断面を決定して部材の 構造設計を行った。

図-2, 図-3に秋間トンネルの内型枠荷重条件と計算 モデルを示す。

\section{3 内型枠の機構と装備数}

内型枠は覆工コンクリートの仕上がり径に対応して数 個のピースに分割されている。型枠の幅はこれまでの実 績上 $1.2 \mathrm{~m}$ を標準としているが，地山の施工条件や掘 削機の能力等を検討のうえ 1.5 1.8 $\mathrm{m}$ とすることも可 能と考えられる。

装備数は, 推進反力とシールド進行からの両面から検 討することとし， (1)コンクリートと内型枠の付着力およ び摩擦力による推進反力の確保と, (2)最大日進量とのい ずれか大きい方とし, 余裕を 2 ～ 3 リング考慮して決定 することとしている。

また，曲線施工，蛇行修正等に対応するため内型枠間
のテーパー量を調節できるようにし，パッキン等によっ て内型枠の外周方向の継ぎ目間に隙間が生じない構造と する必要がある。

内型枠はシールド進行に伴い, エレクター装置により 最後尾の内型枠の脱型, シールドテール部の組立位置へ の移動, シールドテール内での組立の各作業が可能な構 造とする。

エレクターには走行型と非走行型があり，一般には仕 上がり径打よび施工方法によって選定する。図-4に秋 間トンネルの内型枠とエレクター装置を示す。

\section{4 妻枠の機能}

妻枠はシールドテールプレートを含む内型枠の端部の 型枠装置で，次の機能を有するとともに，所要の強度を 有するものでなければならない。

（1）コンクリート圧力調整機能

妻枠装置は打設コンクリートの圧力を保持し，これを 調整できる機能を必要とする。このため妻枠本体はシー ルドテール軸心に対して垂直とし，妻枠ジャッキにより スキンプレート内側および内型枠外側に常に接して搖動 できる構造としなければならない。また，コンクリート 打設圧力, 水圧を確実に遮断できるとともに, シール機 構は交換できる構造とする必要がある。

（2）コンクリート漏洩防止機能

妻枠装置はコンクリート端面の型枠の役割として，コ ンクリート材料, 地下水等のシールド内への漏洩防止機 能を必要とする。シール機構については，(1)妻枠のシー ルドテールスキンプレート側は, 止水目的とスキンプ レートの変形量を吸収するためゴム等によるシールを装 備する。また，内型枠側は内型枠がかならずしも所定の 位置ではなく偏心したり曲線施工で位置がずれる場合も あることから，これに追従でき，かつ内型枠との替動， 摩擦および所定のコンクリート圧力等に耐え得る構造と しなければなければならない。材料，機構の研究・開発

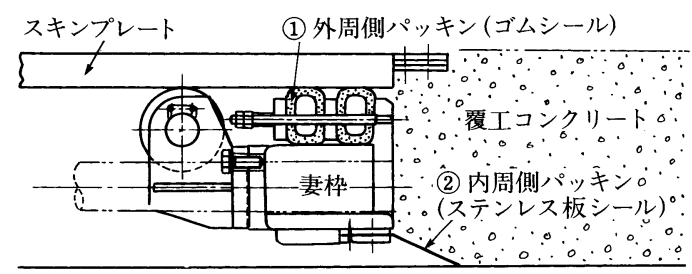

図-5＼cjkstart秋間トンネルの妻枠装置
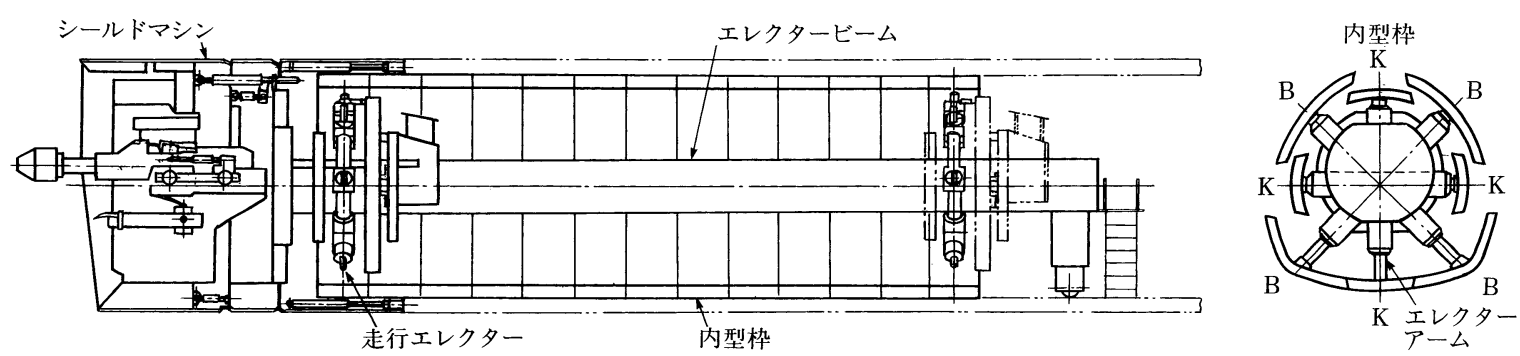

図-4 秋間トンネルの内型枠とエレクター装置 
および試験等による検証の結果, (2)ステンレスばね鋼を 主体とした構造としている。

図-5に秋間トンネルの妻枠装置を示す。

覆工コンクリートの打込みは，妻枠に設けられた 12 孔の打込み口から分配弁を介してバランス良く行われ る。これらの制御は掘進，コンクリートの打込み，妻型 枠に作用するコンクリート压力等の諸データをリアルタ イムに処理して常に適切な対応策が選択可能な施工管理 システムによって行われている。

4.おおりに

トンネル建設の合理化は, トンネルが線状構造物であ
ることから作業がすべて直列的となり，坑奥との併行作 業を前提に高能率化を検討する必要がある。ここで述べ た覆工コンクリートは, 掘削作業との併進のもとで最新 技術を駆使して施工されたものであり，品質はもとより 能率面でも五里ケ峯トンネルの二次覆工では最大月進 $306 \mathrm{~m} /$ 月を，秋間トンネルの ECL では最大月進 200.4 $\mathrm{m} /$ 月を記録してそれぞれ合理化に大きく貢献したばか りでなく, 将来のトンネル技術の方向を示しているもの 亡考えている。今後はこれらの技術のさらなる深度化 と，建設コストダウンを目指していきたいと考えてい る。

《図書案 内》

[コンクリートエ学ブックス・6]

\section{コンクリート工事の施工技術}

一良いコンクリート工事をするための施工技術の基本一-

毛見・篠木・野尻・青景・笠原

清水・十河・寺井・戸祭・松岡

山下・万木・吉信・渡辺 共著

A 5 判・291 ページ/定価 5000 円（税込），会員特価 4500 円（税込）／送料 430 円

良いコンクリート工事とは，品質・施工・経済性の三位一体であり，コンクリート・型枠・鉄筋の一体化でもあります。正しい示 方書や仕様書があっても，また良いコンクリートが供給されても，施工が悪ければ，発注者や設計者の意図と異なり，大きな財産を 失うことになります。

本書は, コンクリート工事の施工に必要な基礎知識の上に計画・準備・打込み・養生・管理の基本を大きな柱とし，さらに応用と して高層ビルやダム工事も対象としたほか，水中コンクリート工事や一部ロボット工法なども今後の施工法として取り上げているた め, コンクリート工事の現場技術者ばかりでなく, スタッフ部門の技術者あるいは施工管理の方々の良き手引書となっています。も ちろん, 生コンメーカ, 混和剤メーカ, さらには型枠・圧送技術者のほか, 設計やコンサル夕ント関係の方々にも大いに参考となる ものです。とくに施工の学習書として，各種の資格試験のテキストに好適といえます。

\section{[主要目次]}

序／I．施工に必要なコンクリートの性質（設計と施工／関連 規準と施工 /材料と施工 /配合と施工 $/$ 養生と管理 $) /$ II. コ ンクリート工事の施工計画（土木関連施工計画／建築関連施工 計画 /施工機械器具 /仮設・型枠支保工の計画) $/$ III. コンク リート工事の準備（生コンの注文／打込みの段取）／IV. 運搬
（運搬の基本 $/$ 各種運搬方法) $/ \mathrm{V}$. 打込み・締固め(打込み・締固 めの原則/大型構造物への打込み・締固め/特殊部位への打込み・ 締固め /地中連続壁への打込み) $/$ VI. 養生（一般／特殊な配慮を 有する養生) /VII. 品質管理・検査（品質管理／検査）／索引

- 申込先：(社）日本コンクリート工学協会・管理課「書籍販売係」

干102 東京都千代田区麦匊町 1-7 相互半蔵門ビル 12 階 /電話 (03) 3263-1571 (担当 : 宇野)

$<申$ 込方法 $>$ 書籍名・送付先を明記のうえ，前金 (現金書留) にてお申込み下さい。 